\title{
MENCERMATI PILIHAN RAKYAT ANTARA POPULARITAS DALAM INTEGRITAS SEMU
}

\author{
Suardi \\ ${ }^{1)}$ Dosen Jurusan Ilmu Komunikasi, Fakultas Dakwah dan Komunikasi,UIN Suska Riau, \\ Jl. HR Soebrantas Km 15 Simpangbaru, Tampan, Pekanbaru 50275 \\ Email: suardi.mikom@gmail.com
}

\begin{abstract}
Abstrak
Popularitas tampaknya telah menjadi salah satu perhatian tersendiri ditengah keterbukaan informasi saat ini. Populer dianggap menjadi salah satu bagian dari sukses, baik kalangan Politisi, Selebriti, Bisnisman, Enterpreneur, pekerja, bahkan pelajar dan akademis. Dibidang politik, banyak partai politik di Indonesia saat ini yang melihat popularitas sebagai "magnet" dalam mengangkat elektebilitas partainya. Boleh jadi ini jugalah yang melatar belakangi orang-orang dari berbagai kalangan, kini seakaan berlomba mengejar popularitas. Bahkan walaupun harus dengan "menghalalkan" segala cara. Termasuk melakukan hal-hal yang kontroversial atau "nyeleneh". Lalu apakah popularitas saat ini masih menjadi faktor utama dalam menentukan pilihan rakyat, ditengah derasnya akses informasi media massa saat ini? Bagaimana pula jika Popularitas dicapai dengan integritas semu? Masihkah berdampak positif pada pilihan dan minat rakyat? Bagaimana pula fenomena terbaru ditengah masyarakat yang kian cerdas menyikapi popularitas dalam integritas semu saat ini? Meskipun diawal-awal reformasi teori jarum hipordemik tampak begitu perkasa mempengaruhi masyarakatyang konon dinegara-negara maju sudah lama ditinggalkan-dimana popularitas menjadi faktor utama. Masyarakat tampaknya sudah mulai belajar, dari kasus-kasus popularitas dalam integritas semu. Salah satunya, kasus Bupati Ogan Ilir, dan kasus-kasus korupsi yang menimpa kepala daerah lainnya. Artinya masyarakat secara umum sudah mulai kritis, dimana popularitas dalam elektabilitas calon kepala daerah tidak lagi menjadi penentu utama pilihan rakyat.
\end{abstract}

Kata kunci: Pilihan rakyat, popularitas, integritas semu.

\section{Pendahuluan}

Berbagai cara dilakukan orang-orang demi meraih popularitas, apalagi seiring berkembangnya teknologi informasi saat ini. Baik dalam bentuk media sosial, Blog, Web dan media online lainnya. Ditambah lagi pengguna dan peminat media sejenis, yang tumbuh kian pesat akhir-akhir ini. Tak hanya terbatas dikalangan tertentu, namun sudah menyentuh berbagai lapisan masyarakat.
Tak pelak lagi melihat kondisi dewasa ini, menjadi peluang tersendiri kalangankalangan tertentu termasuk para pengejar popularitas demi tujuan-tujuan tertentu pula. Baik kalangan Politisi, Selebriti, Bisnisman, Enterpreneur, pekerja, bahkan pelajar dan akademisi. Mengutip salah satu artikel pada kolom "Showbiz situs berita liputan enam (11/8/2017) dengan judul "Demi Popularitas, Istri Sebar Video Pribadi Andika Kangen Band?" sangat tercermin bagaimana 
popularitas begitu di "buru" kalangankalangan tertentu.

Karena tak dipungkiri Terkenal dan populer tampaknya telah menjadi salah satu bagian dari sukses. Tak heran jika David $j$ Schuwartz pengarang buku berpikir dan berjiwa besar yangg jadi salah satu buku best seller dunia mengatakan, "sukeses berarti popular dikalangan teman, lingkungan dan masyarakat luas". Jadi sedemikian pentingkah arti popularitas itu dalam kesuksesan?.

Setidaknya mau tak mau harus kita akui juga, kadang popularitas memang bisa berpengaruh pada kredibilitas seseorang.Meski tak jarang kredibilitas itu, terkadang hanyalah sekedar kredibilitas semu (tak sesuai dengan yang sebenarnya). Artinya, seseorang yang sebenarnya hanya punya kemampuan dan skil biasa-biasa saja, namun karena ia lebih populer, maka bisa saja dianggap kemudian lebih kompeten ketimbang yang lain yang lebih punya kemampuan.

Didunia politik dan di era pemilihan langsung saat ini, popularitas tampaknya juga telah menjadi salah satu perhatian tersendiri.Banyak partai politik di Indonesia saat ini yang melihat popularitas sebagai "magnet" dalam mengangkat elektebilitas partainya.Tak heran, partai politik pun seakan berlomba-lomba meminang orang orang yg dianggap memiliki popularitas tinggi.Baik dikalangan selebriti, pejabat, penggiat sosial, pengusaha dan profesi lainnya.

Boleh jadi ini jugalah yang melatar belakangi orang-orang dari berbagai kalangan, kini seakaan berlomba mengejar popularitas. Bahkan walaupun harus dengan "menghalalkan" segala cara. Termasuk melakukan hal-hal yang kontroversial atau "nyeleneh". Memang jika semata untuk tujuan popularitas, cara ini bisa saja dilakukan. "Bul 'alaa zamzam Fatu'raf", begitu kira-kira bunyi pepatah arab, yang artinya kencingi telaga zamzam, maka kamu akan terkenal. Pepatah itu setidaknya mencerminkan bagaimana popularitas bisa dicapai dengan melakukan halhal aneh atau tindakan-tlindakan kontroversial.
Lalu apakah popularitas menjadi faktor utama dalam menentukan pilihan rakyat, ditengah derasnya akses informasi media massa saat ini? Bagaimana pula jika Popularitas dicapai dengan integritas semu?Masihkah berdampak positif pada pilihan dan minat rakyat? Bagaimana pula fenomena terbaru ditengah masyarakat yang kian cerdas menyikapi popularitas dalam integritas semu saat ini?

Karena persoalan ini tampaknya mulai menimbulkan kekhwatiran-kehawatiran tersendiri. Dimana, politik yang hanya berbasis popularitas di Indonesia yang sedang marak saat ini bisa saja berpeluang besar memunculkan pemimpin instan, tidak kompeten, dan miskin integritas

\section{A. PEMbahasan}

\section{Pililihan Bersumber dari Minat}

Elizabeth B. Hurlock dalam buku Child Development Sixd Edition (1978:114) mengatakan minat merupakan sumber motivasi yang mendorong manusia untuk melakukan apa yang mereka inginkan apabila mereka bebas memilih. Bila orang melihat bahwa sesuatu akan menguntungkan, mereka merasa berminat. Adanya minat ini kemudian mendatangkan kepuasan, bila kepuasan berkurang, minat pun akan berkurang.

Sedangkan Laster D. Crow dan Alice Crow (1963:25), memberikan pengertian "An interesting is motivating force that impels an individual toward participation in one activity rather than another"minat adalah kekuatan motif yang mendorong seseoraang ke arah ikut serta dalam suatu kegiatan yang lebih disukai daripada yang lain.

Minat berbeda dengan kesenangan.Kesenangan hanya bersifat sementara sebaliknya minat bersifat menetap dan cenderung agak lama.Minat lebih tetap (persistent) karena minat memuaskan kebutuhan yang penting dalam kehidupan seseorang.

Artinya minat dapat mempengaruhi pilihan dan tindakan seseorang dalam 
memutuskan sesuatu (pilihan). Dikarenakan minat berkaitan erat dengan motivasi, karena motivasi muncul disebabkan kebutuhan begitu juga timbulnya minat. Sehingga dapat dikatakan bahwa, minat adalah alat motivasi yang pokok. Hal ini sesuai dengan pendapat Elizabeth B. Hurluck (1978:420) mengatakan, interest are sources of motivation which drive people to do what they want to dominat adalah sumber motivasi yang mengarahkan seseorang untuk berbuat apa yang mereka kehendaki (pilihan).

Dengan demikian minat mempunyai peranan penting di dalam semua aktivitas dan tindakan manusia, tidak terkecuali dalam memilih sosok pemimpin. Sebab, dari sini akan muncul perasaan senang atau tidak senang terhadap sesuatu, yang akhirnya mempengaruhi seseorang kedepan untuk berbuat atau tidak berbuat. Sehingga, besar kecilnya minat atau tinggi rendahnya minat akan mempengaruhi rakyat untuk menggunakan hak pilihnya dalam memilih sosok calon pemimpin.

Hurlock (1978:116-117) menjelaskan bahwa semua minat mempunyai tiga aspek, yaitu sebagai berikut:

1. Aspek kognitif, yaitu aspek yang dikembangkan seseorang mengenai bidang yang berkaitan dengan minat. Aspek ini berkembang dari pengalaman pribadi dan apa yang dipelajari di rumah, di sekolah, dan di masyarakat seta di berbagai jenis media massa.

2. Aspek afektif, yaitu konsep yang membangun aspek kognitif yang dinyatakan dalam sikap yang ditimbulkan minat. Aspek afektif ini berkembang dari pengalaman pribadi dari sikap orang yang terhadap kegiatan yang berkaitan dengan minat tersebut.

3. Aspek psikomotor, yaitu aspek yang berjalan dengan lancar tanpa perlu pemikiran lagi.

\section{Z. Kasijan dalam buku Psikologi} mengatakan bahwa minat dapat menunjukkan kemampuan untuk memberikan stimulasi yang mendorong kita untuk memperhatikan seseorang, suatu barang, atau kegiatan atau sesuatu yang dapat memberikan pengaruh terhadap pengalaman yang telah distimuli oleh kegiatan itu sendiri (Sumanto, 1984: 351).

Sejalan dengan itu Sobur (2003:246) mendefinisikan minat erat hubungannya dengan perhatian yang dimiliki seseorang, karena perhatian mengarahkan timbulnya kehendak pada seseorang, Kehendak atau kemauan ini juga erat hubungannya dengan kondisi fisik seseorang misalnya dalam keadaan sakit, capai, lesu atau mungkin sebaliknya yakni sehat dan segar. Juga erat hubungannya dengan kondisi psikis seperti senang, tidak senang, tegang, bergairah dan seterusnya.

Menurut Crow \& Crow dalam (1993:112) minat adalah sesuatu yang berhubungan dengan daya gerak yang mendorong kita cenderung atau merasa tertarik pada orang, benda, kegiatan ataupun bisa berupa pengalaman yang efektif yang dirangsang oleh kegiatan itu sendiri

Dari beberapa definisi di atas dapat ditarik kesimpulan tentang minat, bahwa minat merupakan motivasi sebagai kekuatan pembelajaran yang menjadi daya penggerak seseorang dalam melakukan aktivitas dengan penuh ketekunan dan cenderung menetap, dimana aktivitas tersebut merupakan proses pengalaman belajar yang dilakukan dengan penuh kesadaran dan mendatangkan perasaan senang, suka dan gembira.

Dengan demikian minat mempunyai peranan penting di dalam semua aktivitas manusia, tidak terkecuali dalam menentukan pilihan terhadap calon pemimpin. Sebab, dari sini akan muncul perasaan senang atau tidak senang terhadap sesuatu, yang akhirnya mempengaruhi seseorang untuk berbuat atau tidak berbuat dalam menentukan pilihannya ketika menggunakan hak pilih pada seorang calon pemimpin. Sehingga, besar kecilnya minat atau tinggi rendahnya minat akan mempengaruhi khalayak masyarakat dalam menentukan piihan. 
Artinya dalam konteks mencermati pilihan rakyat dalam memilih calon pemimpin dewasa ini, para politikus perlu lebih cermat dan hati-hati serta memelukan persiapan matang dan sistematis. Sebab Untuk mendukung minat yang besar perlu dibangun motif-motif tertentu dalam batin seseorang. Crow dan Crow menyebutkan lima motif penting yang dapat mendorong seseorang untuk melakukan minat dengan sebaik-baiknya. Adapun kelima motif tersebut yaitu sebagai berikut:

1. Suatu hasrat untuk mendapatkan suatu hal yang baik,

2. Suatu dorongan baik untuk memuaskan rasa ingin tahu terhadap sesuatu,

3. Hasrat untuk meningkatkan pertumubuhan dan perkembangan secara pribadi,

4. Hasrat untuk menerima pujian dari orang lain, dan Cita-cita untuk sukses di masa depan dalam suatu bidang khusus.

Seiring dengan yang dikemukakan Crow dan Crow diatas, terdapat teori yang berhubungan dengan minat yaitu teori "law of readiness" (hukum kepuasan). Teori ini dikembangkan oleh Thorndike pada abad ke20.Teori ini menegaskan tentang kesiapan individu untuk melakukan sesuatu. Jika kesiapan telah ada pada diri seseorang, maka dia akan melakukan tindakan dengan sepenuh hati, sebaliknya jika kesiapan itu tidak ada, maka dia akan melakukan tindakan dengan mendua hati atau tidak sungguh-sungguh (Suryabrata, 1983:18).

Tidak sungguh-sungguh disinilah yang menurut penulis dalam tulisan ini sebagai hal yang semu. Artinya, hanya sekedar kamuplase untuk tujuan-tujuan tertentu, namun bukan gambaran yang sebenarnya. Dari teori diatas tindakan dan aktivitas serta integritas semu yang di publish atau dimuat dimedia massa, tidak akan mencapai hasil sesuai dengan apa yang diharapkan.

Bahkan dalam perjalanannya justru bisa saja berbalik menimbulkan hasil atau kesan yang buruk bagi pengirim pesan yang bisa merubah sikap masyarakat. Misalnya ketika seorang calon mengumbar sikap kepedulian terhadap rakyat kecil di media massa yang hanya bersifat semu dan tidak dilandasi sikap yang sebenarnya. Jika dalam perjalanannya hal itu tak tampak dalam kesungguhan sikap, bisa saja hal yang pernah dimuat tersebut berbalik menjadi landasan ketidak sukaan masyarakat, karena tak sesuai fakta yang sesungguhnya.

\section{Popularitas}

Popularitas berarti ketenaran (Partanto,2001:601). Popularitas berasal dari kata populer, artinya dikenal dan disukai orang banyak (Poerwadarminta, 2006: 907).Dalam Kamus Umum Bahasa Indonesia popularitas berarti ketenaran yang dimiliki seseorang (Poerwadarminta, 2006:769). Popularitas mempunyai arti yang sama dengan familiarity. Familiarity artinya sering terlihat atau sudah terkenal.

Dalam Ilmu Komunikasi menyangkut Popularitas, terdapat kalimat yang mengatakan "He doesn't communicate what he says, he communicates what he is" ia (komunikator) tidak dapat menyuruh pendengar hanya memperhatikan apa yang ia katakan namun pendengar juga akan memperhatikan siapa yang mengatakan (Riswandi, 2009:129).

Terkait Popularitas, Robert B. Zajonc (1968) telah melakukan penelitian dengan cara memperlihatkan foto-foto wajah pada subjeksubjek eskperimennya. Ia menemukan bahwa makin sering subjek melihat wajah tertentu, ia makin menyukainya. Penelitian ini melahirkan hipotesis "mere eksposure" (terpaan saja). Hipotesis ini dijadikan sebagai landasan ilmiah akan pentingnya repetisi pesan dalam mempengaruhi dan pendapat (Rahmat, 2008:115).

Jadi tak bisa dipungkiri juga, bahwa popularitas sangat berperan dalam menentukan minat dan pilihan masyarakat. Namun disisi lain, popularitas yang hanya dilandasi integritas semu, tak akan mencapai hasil maksimal ditengah masyarakat yang kian cerdas. Terbukti akhir-akhir ini indikator tersebut kian tampak, 
terutama dalam pemilihan-pemilihan kepala daerah diberbagai pelosok tanah air akhir-akhir ini.

\section{Integritas Semu}

Interitas dewasa ini, cenderung sangat terkait dengan kepemimpinan. Bahkan jika mendengar kata integritas, hal yang pertama kali terngiang di benak penulis adalah permasalahan kepemimpinan. Hal itu wajar, karena dewasa ini masalah kepemimpinan memang sering kali dikait - kaitkan dengan istilah yang satu ini. Integritas menjadi syarat utama kepemimpinan.Ada banyak ahli manajemen yang mengatakan bahwa setiap pemimpin yang berhasil, selalu dilandasi dengan integritas yang tinggi. Menurut mereka, tanpa integritas yang tinggi, kepemimpinan yang dilaksanakannya tidak akan sukses atau pun berhasil.

Kata integritas pada dasarnya berasal dari bahasa Latin yaitu dari Kata Integer yang artinya lengkap atau pun utuh.Jika diartikan dari asal katanya, maka kata integritas dapat diartikan sebagai sebuah usaha yang utuh dan lengkap yang didasari dengan kualitas, kejujuran, serta konsistensi karakter seseorang.

Ippho Santoso (2010) mengatakan integritas akan melahirkan reputasi dan reputasi akan akan melahirkan kepercayaan. Integritas sering diartikan sebagai satunya pikiran, perkataan dan perbuatan.Jika merujuk pada kata asalnya, yaitu integer dan integration, maka integritas mempunyai makna berbicara dengan utuh dan sepenuh-penuhnya.

Menurut Henry Cloud (2007) ketika berbicara tentang integritas, kita berbicara tentang tentang menjadi orang yang utuh, yang terpadu, dan seluruh bagian diri kita yang berlainan bekerja dengan baik dan berfungsi sesuai rancangan.Ini mengenai keutuhan dan keefektifan sebagai orang.Ini benar-benar "bekerja dengan kekuatan penuh".

Sedangkan Semu menurut Kamus Besar Bahasa Indonesia Semu adalah tampak seperti asli (sebenarnya), padahal sama sekali bukan yg asli (sebenarnya). Jadi Integritas Semu adalah sebuah usaha yang utuh dan lengkap yang didasari dengan kualitas, kejujuran, serta konsistensi karakter seseorang yang hanya dibuat-buat hingga tampak seperti asli.

\section{Mencermati Pilihan Rakyat}

Kembali penulis tegaskan, tak dipungkiri popularitas memang menjadi sesuatu yang sangat menentukan terhadap pengaruh pesan komunikasi. Namun ketika popularitas terkait dengan pilihan, ia harus dilandasi kesiapan dan kesungguhan komunikatornya. Popularitas yang dicapai dengan tindakan atau aktifitas yang dilakukan serampangan atau tidak sungguhsungguh (semu) akan mempengaruhi rakyat dalam menentukan pilihan ditengah masyarakat kita yang kian cerdas.

Memang diera kebebasan dan keterbukaan informasi saat ini, peluang populer dengan instan lewat hal-hal aneh dan kontroversial seakan terbuka lebar. Bahkan sudah tampak mulai menggejala, khususnya dikalangan pengejar popularitas.Mulai dari kalangan selebriti, politikus, pejabat, pengusaha dan lain sebagainya.Tujuannya, tentu saja agar lebih dikenal, populer, demi mengejar sukses.

Jika mengamati penomena saat ini, seorang pejabat negara yang mengeluarkan kata-kata kasar dan tak semestinya di media massa, bisa lebih populer. Sorang aparat kepolisian yang bertingkah konyol diluar koridor, difollow updi media massa, bisa melejit jadi terkenal. Begitu juga ketika seorang tokoh menyampaikan pemikiran-pemikiran kontroversial dimasyarakat malah menjadi terkenal.Seorang pengacara dengan segala kontroversi sikap dan kehidupan pribadinya, menjadi popular.

Dalam perjalanannya, hal ini kemudian tampaknya mulai menimbulkan ketakutan banyak pihak kususnya di bidang politik. Dimana, politik yang hanya berbasis popularitas di Indonesia yang sedang marak saat ini bisa saja berpeluang besar memunculkan pemimpin instan, tidak kompeten, dan miskin integritas. Syamsuddin Haris (Kompas, 20/8/2015). Calon-calon 
Pemimpin yang belum "matang", namun popular karena berbagai faktor, bisa saja muncul sebagai pemenang. Mengalahkan calon terbaik dari segi aksetabilitas, karena kalah pupuler dimasyarakat.

Kasus yang menimpa bupati Ogan Ilir Sumatera Selatan, yang digrebek BNN saat diduga sedang pesta sabu di rumah dinasnya, boleh jadi salah satu bentuk dampak dari terpilihnya sang pemimpin yang hanya berbasis politik popularitas. Hal itu mengingat juga latar belakang sang bupati, yang tak lain anak dari bupati sebelumnya, walau pun masih dalam usia yang masih tergolong belia.

\section{Dampak Media Massa}

Jika merujuk pada kajian dampak media massa dalam komunikasi, memang terdapat tiga tahapan dampak pesan komunikasi massa terhadap publik. Tahapan pertama dinamakan dampak kognisi.Kognisi merupakan tahapan dimana pesan komunikasi yang disampaikan, singgah di alam pikiran seseorang. Pembaca atau pemirsa menjadi ingat, tahu dan kenal terhadap apa yang dinformasikan penyampai informasi.

Ditahapan inilah para pencari popularitas itu cenderung memainkan perannya. Berbagai cara pun dilakukan yang penting ia bisa menanamkan sosok dirinya pada benak pembaca atau pun pemirsa. Sasarannya, tentu saja masyarakat awam yang masih terkungkung dengan anggapan bahwa semua yang disampaikan di media massa itu maha benar. Sedangkan mereka sendiri sama sekali tak punya daya kritis, atas apa yang diinformasikan. Dalam kajian komunikasi hal ini dikenal dengan Teori jarum hipodermik disebut juga dengan Magic Bullet atau Stimulus Response Theory. Menurut teori ini, media massa memiliki dampak yang sifatnya langsung, segera serta kuat terhadap khalayak massa. Media massa pada kurun waktu 1940an hingga 1950an digambarkan memiliki pengaruh yang sangat kuat terhadap perubahan perilaku

Tahapan kedua dinamakan asfek afektif.Asfek afektif ini lebih kepada sikap, perasaan, atau emosional. Misalnya ketika pemirsa atau pembaca menerima pesan komunikasi di media massa, maka tak hanya sebatas tahu atau ingat. Namun berlanjut pada memunculkan perasaan, baik menyukai atau malah membencihi pesan atau si penyampai pesan. Disinilah para pencari popularitas yang "menghalakan" segala cara, mesti hati-hati.

Sebaliknya, para pembaca atau pemirsa juga harus lebih lanjut dan bijak mengolah informasi yang diterimanya pada tahap afektif, jangan sampai pada tahap kognitif saja.Sehingga para pemirsa atau pembaca tak hanya terjebak pada populraitas dan integritas semu semata. Terkenal atau popularitas sang penyampai pesan. Namun, berlanjut pada penghargaan atau simpati, layak atau tidaknya penyampai pesan disukai atau malah lebih layak dibencihi.Jadi disamping ingat, namun juga melahirkan sikap.

Tahapan ketiga dinamakan asfek konatif.Dimana afek ini lebih menyangkut pada tindakan atau perilaku.Setelah dikenal, dirasakan dengan persaan, akhirnya sampai pada konatif atau tindakan nyata.Apa tindakan kita pada pesan atau sang penyampai pesan atau komunikator. Ketika ia seorang calon kepala daerah, apakah dengan informasi-informasi yang diterima dari media massa selama ini, layak atau tidakkah kita menjatuhkan pilihan padanya. Dengan segala integritas, kompetensi yang melekat padanya. Sebagai masyarakat, kita juga harus sudah bisa menilai aksetabilatasnya sebagai calon pemimpin bagaimana?.

\section{Kondisi masyarakat kita}

Mencermati masyarakat kita saat ini, tampaknya mulai ada pergeseran, terutama pada komunikasi politik. Meskipun diawal-awal reformasi teori jarum hipordemik tampak begitu perkasa mempengaruhi masyarakat- yang konon dinegara-negara maju sudah lama ditinggalkan-dimana popularitas menjadi faktor utama. Masyarakat tampaknya sudah mulai belajar, dari kasus-kasus popularitas dalam integritas semu. Salah satunya, kasus Bupati 
Ogan Ilir, dan kasus-kasus korupsi yang menimpa kepala daerah lainnya.

Artinya masyarakat secara umum sudah mulai kritis, dimana popularitas dalam elektabilitas calon kepala daerah tidak lagi menjadi penentu utama pilihan rakyat. Indikataor ini bisa dilihat dari pemilihanpemilahan kepala daerah baru-baru ini. Dimana populritas tidak lagi menjadi penentu pilihan rakyat. Pada kasus Pilkda DKI Jakarta misalnya, pasangan Ahok-Djarot yang popularitasnya begitu tinggi dari berbagai lembaga survei, ternyata kalah dalam pilihan rakyat. Begitu juga di daerah, calon-calon yang hanya mengumbar popularitas dalam integritas semu dengan pernyataan, dan misi kontoversial ternyata tak dipilih rakyat. Meskipun sang calon begitu populer di tengah masyarakat.

\section{B. PENUTUP}

Mungkin apa yang dibeberkan Lembaga Survei Indonesia (LSI) terkait integritas dalam kualitas pemimpin yang di dambakan rakyat saat ini bisa jadi acuan kita bersama. Yakni, jujur, berempati, tegas dan pintar (LSI;2007). Memang dalam politik popularitas, "kemasan" menjadi salah satu yang dikritik sebagai artificial. Namun dengan sikap yang proporsional dalam menerima dampak informasi media massa, popularitas bukan lagi sekedar pada integritas semu. Namun mampu menjadi energy untuk melakukan perubahan praktis.

Hal yang didamba masyarakat tentang kualitas pemimpin juga tak kontraproduktif.Dimana antara popularitas dan intergritas serta kapabilitas tak sejalan, bahkan malah berbanding terbalik.Disinilah diperlukan kesadaran kita bersama. Sebagai partai politik, jangan hanya mengandalkan popularitas dan elektabiloitas, melainkan juga punya tanggungung jawab moril dari sisi aksetabilitas

Sedangkan sebagai masyarakat kita juga harus mulai selektif, peduli dan menyadari. Saat menjatuhkan pilihan pada sang calon pemimpin, jangan hanya bedasarkan ketenaran sang calon saja. Namun apakah dibalik ketenaran dan popularitas itu, dari informasi yang saat ini banyak berseliweran sudah mencerminkan sosok calom pemimpin yang jujur, berempati pada rakyat, tegas dan pintar?Ataukah popularitas sang calon, lahir dari integritas, atau malah kontrovesi, nyelenah dalam integritas semu?. Sekali lagi, sebagai masyarakat mari kita mulai lebih selektif, peduli dan menyadari. Dengan demikian, mudah-mudahan sebagai rakyat kita tak terjebak dengan popularitas dan integratis semu sang calon pemimpin. Ditengah keterbukaan dan kebebasan informasi saat ini.

\section{DAFTAR KEPUSTAKAAN}

Alex Sobur. (2003). Psikologi Umum. Bandung: Pustaka Setia

Drs.Jalaludin Rakhmat,M.Sc.(2008). Psikologi Komunikasi. Bandung. PT. RemajaRosdakarya

Elizabeth B. Hurlock, (1978), SChild Development Sixd Edition,McGraw-Hill Education

Henry Subiakto, Rachmah Ida; (2012), Komunikasi Politik, Media dan Demokrasi, Jakarta, Prenada Media Group.

Ippho Santosa(2010) 7 Keajaiban Rezki, Jakarta PT. Alex Media Komputindo

Laster D. Crow dan Alice Crow, (1983), Educational psychology,New York : American Book Co

Poerwadarminta, W.J.S. (2006). Kamus Umum Bahasa Indonesia. Jakarta: Balai Pustaka

Sumanto; (1984) Psikologi Pendidikan.Jakarta: Bina Aksara

Suryabrata Sumadi, (1984).Psikologi Pendidikan, Jakarta : Rajawali, 